\title{
Efektivitas Variasi Konsentrasi Ekstrak Etanol Daun Ketepeng Cina terhadap Pertumbuhan Shigella dysentriae
}

\author{
Variation Effectivity of Concentration Ketepeng Cina Ethanol Leaf Extract Growth Against Shigella \\ dysentriae
}

Yusianti Silviani* dan Leonardo Bagus Utomo

Sekolah Tinggi Ilmu Kesehatan Nasional

*Corresponding author: yusianti.silviani@gmail.com

\begin{abstract}
ABSTRAK
Disentri basiler merupakan infeksi yang ditemukan di Indonesia dengan prevalensi tinggi. Salah satu bakteri penyebab disentri basiler adalah Shigella dysentriae. Alternatif pengobatan menggunakan bahan alami,yakni ekstrak ketepeng cina. Tujuan penelitian mengetahui efektivitas ekstrak etanol daun ketepeng cina terhadap pertumbuhan Shigella dysentriae.

Jenis penelitian analitik eksperimental dengan pendekatan post test with control dan teknik sampling non random quota sampling. Daun ketepeng cina diperoleh di Desa Karangsari,Tawangmangu dengan teknik quota sampling. Daun ketepeng cina diekstrak secara maserasi dan dibuat berbagai konsentrasi menggunakan aquadest steril.

Konsentrasi yang digunakan pada penelitian adalah 12,5\%, 25\%,50\%, 100\%, dan menggunakan antibiotik ciprofloksasin 5 ug sebagai kontrol positif. Adanya efek ekstrak Daun Ketepeng Cina terhadap pertumbuhan Shigella dysentriae ditunjukkan ada zona hambat pada media NA. Uji Kruskal-wallis didapatkan p 0.000 yaitu lebih kecil dari $\alpha(0,05)$, konsentrasi optimum penelitian adalah $100 \%$.

Variasi konsentrasi ekstrak ketepeng cina efektif mennghambat pertumbuhan Shigella dysentriae dengan metode difusi cakram.
\end{abstract}

Kata kunci: efektivitas, ekstrak daun ketepeng cina, Shigella dysentriae

\section{ABSTRACT}

Basiler dysentriae is an infection that most find in Indonesia. It has prevalention higher relative. One of bacterial that cause basiler dysentriae is Shigella dysentriae. Alternative option can be done is nature, Ketepeng Cina leaf extract. The purpose of this research is to know inhibitory effect of Ketepeng Cina etanol leaf exctract to the growth of Shigella dysentriae.

This research is using experimental analitic research, post test with control design by non random quota sampling technique.Ketepeng Cina leaf that can be found at Desa Karangsari, Tawangmangu. Ketepeng Cina leaf is extracted maserately and it is made by many kind of concentration aquadest.

The concentrations that using in this research are 12,5\%,25\%,50\%,100\% and using ciprofloxasin antibiotic $5 \mu \mathrm{g}$ as positive control. The effect of Ketepeng Cina Extract (Cassia alata Linn) to the Shigella dysentriae growth showed by inhibitory zone in NA media. On Kruskalwallis test showed the $p$ (value) was 0,000 smaller than $\alpha(0,005)$, optimum concentration of this research is $100 \%$.Various concentrations of Ketepeng Cina extract is effective to inhibit the growth of Shigella dysentriae in well-diffusion method.

Keywords: efectivity, ketepeng cina leaf exctract, Shigella dysentriae

\section{PENDAHULUAN}

Shigella merupakan penyebab disentri basiler, Angka kejadian tinggi ditemukan pada anak dengan tingkat kematian sebesar 40\%. (WHO, 2009). Cakupan penemuan dan penanganan diare di Jawa Tengah pada Tahun 2008 - 2009 mengalami peningkatan, bahkan Tahun 2012 masih 42,66\% tingkat kabupaten/kota (Abdullah, 2012).

Shigella dysentriae merupakan bakteri pathogen usus, bersifat gram negatif, batang pendek, tidak berspora, tidak berflagel, dan memiliki kapsul. Bakteri ini memiliki 2 jenis toksin yakni endotoksin dan eksotoksin (Radji, 2011).

Penggunaan antibiotika tidak rasional di ma- 
syarakat membuat angka resistensi terhadap mikroba tinggi sehingga terjadi kegagalan pengobatan. Hal tersebut mendorong masyarakat mencari alternative pengobatan berupa tanaman herbal (Adila, 2013).

Salah satu tanaman yang dimanfaatkan sebagai obat yakni ketepeng cina. Masyarakat memanfaatkan ketepeng cina sebagai obat panu, kudis, dan kurap. Sule (2010) menyatakan daun ketepeng cina mengandung senyawa antibakteri dan antijamur yaitu tannin, saponin, alkaloid, steroid, terpenoid, flavonoid, dan antrakuinon. Penelitian Yakob dan Endriyati (2010) menyimpulkan ekstrak etanol daun ketepeng cina mampu menghambat pertumbuhan Staphylococcus aureus. Senada dengan penelitian tersebut Kurniawan (2012) menyatakan ekstrak alkohol ketepeng cina mampu menghambat pertumbuhan mikroba Escherichia coli, Bacillus subtilis, Salmonella typhi, Pseudomonas aeroginosa, dan Staphylococcus aureus.

Tujuan penelitian ini adalah untuk mengetahui efektifitas ekstrak etanol dan ketepeng China terhadap pertumbuhan Shigella dysentriae.

\section{METODE PENELITIAN}

Desain penelitian yang digunakan adalah analitik eksperimental dengan post test with control. Pengambilan sampel di Desa Karangsari Tawangmangu, Karanganyar dengan teknik quota sampling. Daun yang diambil merupakan daun yang segar, berwarna hijau, utuh dan tidak berlubang (Timothy et al., 2012). Ekstrak daun ketepeng cina merupakan sediaan kental dari proses ekstrak daun ketepeng cina dengan metode maserasi menggunakan pelarut etanol $80 \%$ pada konsentrasi 100\%, 50\%, 25\%, 12,5\% (Yacob \& Endriani, 2010).

\section{Pembuatan Ekstrak}

Pembuatan ekstrak dilakukan dengan cara mengeringkan 700 gr daun ketepeng cina pada suhu kamar selama 3 sampai 4 hari, kemudian daun yang telah kering digiling halus. Serbuk daun ketepeng cina yang telah kering ditimbang sebanyak 500 gram. Sebanyak 500 gram dimaserasi dengan pelarut etanol $80 \%$ sebanyak 5 liter selama 5 hari perendaman dengan pengadukan selama 30 menit setiap hari. Etanol dan air dalam maserat diuapkan dengan evaporator sehingga didapatkan ekstrak kental sebanyak 75 gram.

Selanjutnya ekstrak dengan konsentrasi 100\% diencerkan dengan aquadest (Yacob \& Endriani, 2010).

1) Konsentrasi $50 \%: 2,5 \mathrm{ml}$ dari konsentrasi $100 \%+2,5 \mathrm{ml}$ aquadest.

2) Konsentrasi $25 \%: 2,5 \mathrm{ml}$ dari konsentrasi $50 \%+2,5 \mathrm{ml}$ aquadest.

3) Konsentrasi $12,5 \%: 2,5 \mathrm{ml}$ dari konsentrasi $25 \%$ $+2,5 \mathrm{ml}$ aquadest (Permatasari, 2013).

\section{Pengujian Senyawa Aktif}

Tanin diuji dengan cara sejumlah sampel ditambahkan $5 \mathrm{ml}$ aquadest kemudian dididihkan selama beberapa menit. Kemudin disaring dan filtratnya ditambahkan dengan $\mathrm{FeCl}_{3} \quad 1 \%$. Warna biru tua atau hitam kehijauan yang terbentuk menandakan adanya tanin (Sari, et al., 2015). Cara menguji senyawa flavonoid yaitu sampel ditambahkan serbuk magnesium $0,1 \mathrm{mg}$ dan $0,4 \mathrm{ml}$ amil alkohol (campuran asam klorida $37 \%$ dan etanol $95 \%$ dengan volume yang sama) dan $4 \mathrm{ml}$ alkohol kemudian campuran dikocok. Reaksi positif ditunjukkan terbentuknya warna merah, kuning, atau jingga pada lapisan amil alkohol.

Saponin dideteksi dengan uji busa dalam air panas. Busa yang stabil terus terlihat selama 2 - 4 menit (Chunaifi dan Tukiran, 2014). Untuk mendapatkan konsentrasi 100\%, 10 gr ekstrak ditambahkan ke dalam $10 \mathrm{ml}$ aquades.

\section{Penyiapan Bakteri}

Persiapan sampel bakteri dimulai pada Hari I (Penyuburan Shigella dysentriae): Shigella dysentriae dari biakan murni diambil menggunakan ose bulat steril, Shigella dysentriae dimasukkan ke dalam media Brain Heart Infusion (BHI), Media Brain Heart Infusion (BHI) yang berisi Shigella dysentriae diinkubasi selama 24 jam pada suhu 
$37^{\circ} \mathrm{C}$. Hari II Sampel pada media BHI dilakukan pengecatan gram (Rahmithasuci, 2013). Preparat diamati secara mikroskopis dengan bentuk batang ramping, cat Gram (-), warna sel merah, background merah muda. Setelah itu sampel dari media BHI diinokulasi ke media Mac Conkey secara aseptis. Media Mac Conkey diinkubasi selama 24 jam pada suhu $37^{\circ} \mathrm{C}$. Hari III Pengamatan pada media Mac Conkey diperoleh bentuk ireguler, koloni tidak bewarna, elevasi konveks (cembung), dan tepinya bergerigi (Brooks et al., 2008). Satu koloni dari media MC diinokulasi ke media uji biokimia dan diinkubasi selama 24 jam pada suhu $37{ }^{\circ} \mathrm{C}$. Hari IV Dilakukan uji biokimia dan diamati hasil nya.

\section{Pembuatan Suspensi Bakteri}

Satu ose Shigella dysentriae dari media Mac Conkey, diinokulasi ke media Nutrient Agar (NA) miring. Inkubasi selama 24 jam pada suhu $37^{\circ} \mathrm{C}$. Suspensi bakteri yang telah diinkubasi, diinokulasikan dengan ose steril ke dalam tabung reaksi yang berisi $\mathrm{NaCl} 0,9 \%$ sampai kekeruhannya sama dengan standar Mc. Farland nomor 0,5 (Yacob dan Endriati, 2010). Inokulasi bakteri pada media. Suspensi bakteri pada $\mathrm{NaCl} 0,9 \%$ diinokulasikan ke media NA plate menggunakan kapas lidi steril secara merata pada semua permukaan media, secara aseptis.

\section{Uji Aktivitas Antibakteri}

Letakkan cakram yang sebelumnya dicelupkan ke dalam masing-masing larutan ekstrak 12,5\%, $25 \%, 50 \%$, dan 100\% kurang lebih 1 menit. Kontrol positif menggunakan Ciprofloxacin $5 \mu \mathrm{g}$ dan kontrol negatif menggunakan aquadest steril ke media NA plate yang sudah diinokulasi bakteri. Media diinkubasi pada suhu $37^{\circ} \mathrm{C}$ selama 24 jam.

\section{HASIL DAN PEMBAHASAN}

Identifikasi bakteri Shigella dysentriae dari kultur murni didapatkan morfologi Shigella $d y$ sentriae setelah dilakukan pengecatan gram adalah bentuk batang, susunan menyebar, warna sel

Tabel 1. Morfologi Shigella dysentriae di MC

\begin{tabular}{ll}
\hline Keterangan & : Hasil \\
\hline Bentuk & : Irreguler \\
Warna koloni & $:$ Tidak berwarna (pucat) \\
Elevasi & : Datar \\
Tepian & : Bergerigi \\
\hline
\end{tabular}

Tabel 2 Hasil Uji Biokimia Shigella dysentriae

\begin{tabular}{cccccccc}
\hline \multicolumn{5}{c}{ TSA } & \multicolumn{5}{c}{ SMI } & & \multirow{2}{*}{ Urea } & Cirat \\
Fermatasi & HS & Ges & HS & Indol & Motil & & \\
\hline AlladiAcid & $(-)$ & $(-)$ & $(-)$ & $(-)$ & $(-)$ & $(-)$ & $(-)$ \\
MR & VP & PAD & Gulosa & Manibl & Malosa & Lalitosa & Sulrosa \\
$(-)$ & $(-)$ & $(-)$ & $(+)$ & $(-)$ & $(-)$ & $(-)$ & $(-)$ \\
\hline
\end{tabular}

Tabel 3 Hasil Uji Fitokimia Ekstrak Ketepeng Cina

\begin{tabular}{|c|c|c|}
\hline $\begin{array}{l}\text { Bahan } \\
\text { yang } \\
\text { diuji }\end{array}$ & $\begin{array}{c}\text { Interprestasi } \\
\text { Hasil }\end{array}$ & Hasil \\
\hline Flavonoid & $\begin{array}{l}(+) \text { terbentuk warna } \\
\text { kuning atau jingga } \\
\text { pada lapisan amil } \\
\text { alkohol }\end{array}$ & $\begin{array}{l}\text { (-) Tidak terbentuk } \\
\text { warna kuning atau } \\
\text { jingga pada lapisan } \\
\text { amil alkohol }\end{array}$ \\
\hline Tanin & $\begin{array}{l}(+) \text { Terbentuk } \\
\text { warna biru tua atau } \\
\text { hitam kehijauan }\end{array}$ & $\begin{array}{l}(+) \text { Terbentuk } \\
\text { warna biru tua atau } \\
\text { hitam kehijauan }\end{array}$ \\
\hline Saponin & $\begin{array}{l}(+) \text { Terbentuk busa } \\
\text { stabil dalam } 5 \\
\text { menit }\end{array}$ & $\begin{array}{l}(+) \text { Terbentuk busa } \\
\text { stabil dalam } 5 \\
\text { menit }\end{array}$ \\
\hline
\end{tabular}


Tabel 4.Diameter Zona Radikal Hasil Uji Aktivitas Antibakteri dengan Metode Difusi Cakram

\begin{tabular}{|c|c|c|c|c|c|c|}
\hline \multirow{2}{*}{$\begin{array}{l}\text { Diameter } \\
\text { Zona } \\
\text { Hambat } \\
(\mathrm{mm})\end{array}$} & \multicolumn{6}{|c|}{$\begin{array}{c}\text { Variasi Konsentrasi Bahan Uji Ekstrak daun } \\
\text { Ketepeng Cina }\end{array}$} \\
\hline & $\begin{array}{c}\text { Kontrol } \\
(-)\end{array}$ & $12,5 \%$ & $25 \%$ & $50 \%$ & $100 \%$ & $\begin{array}{c}\text { Kontrol } \\
(+)\end{array}$ \\
\hline I & 0 & 0 & 0 & 0 & 8 & 35 \\
\hline II & 0 & 0 & 0 & 0 & 8 & 35 \\
\hline III & 0 & 0 & 0 & 0 & 7 & 35 \\
\hline IV & 0 & 0 & 0 & 0 & 9 & 36 \\
\hline $\mathrm{V}$ & 0 & 0 & 0 & 0 & 8 & 36 \\
\hline VI & 0 & 0 & 7 & 8 & 10 & 36 \\
\hline VII & 0 & 7 & 7 & 7 & 8 & 37 \\
\hline VIII & 0 & 7 & 7 & 8 & 10 & 36 \\
\hline $\begin{array}{c}\text { Rata- } \\
\text { rata }\end{array}$ & 0 & 1,75 & 2,625 & 2,875 & 8,5 & 35,75 \\
\hline
\end{tabular}

Tabel 5.Uji Kruskal-Wallis Aktivitas Antibakteri Metode Difusi Cara Cakram

\begin{tabular}{ll}
\hline Chi-Square & 36.965 \\
Df & 5
\end{tabular}

Asymp. Sig. $\quad .000$

Tabel 6.Beda Signifikan Uji Aktivitas Antibakteri Metode Difusi Cakram

\begin{tabular}{cc}
\hline Konsentrasi & $\begin{array}{c}\text { Diameter Zona Radikal } \\
(\mathbf{m m})\end{array}$ \\
\hline Kontrol & $0^{\mathrm{a}}$ \\
negatif $(0 \%)$ & $1,75^{\mathrm{a}}$ \\
$12,5 \%$ & $2,62^{\mathrm{a}}$ \\
$25 \%$ & $2,88^{\mathrm{a}}$ \\
$50 \%$ & $8,50^{\mathrm{b}}$ \\
$100 \%$ & $35,75^{\mathrm{c}}$
\end{tabular}

Keterangan :Huruf yang berbeda di belakang angka menunjukkan adanya beda signifikan pada uji Mann - Whitney dengan $\alpha=5 \%$.

merah, sifat Gram (-), background merah muda. Hasil pengamatan morfologi koloni dan uji biokimia disajikan pada Tabel 1 dan 2.

Berdasarkan pengecatan, morfologi koloni dan uji biokimia diketahui bahwa sampel yang digunakan adalah benar $S$. dysentriae (Tabel 2).

Ekstrak etanol daun ketepeng china mengandung senyawa antibakteri flavonoid, tannin dan saponin (Tabel 3).

Konsentrasi rendah 12,5\% ekstrak etanol daun ketepeng cina sudah dapat membentuk zona radikal meskipun rata- rata diameter sangat kecil sebesar 1,75 mm. Seiring peningkatan konsentrasi terjadi peningkatan diameter zona radikal, hingga rata-rata diameter zona radikal sebesar $8,75 \mathrm{~mm}$ pada konsentrasi tertinggi yaitu $100 \%$. Bila dibandingkan kontrol positif Ciprofloksasin
$5 \mu \mathrm{g}$, ekstrak daun ketepeng cina (Cassia alata Linn) memiliki zona hambat lebih kecil dibandingkan Ciprofloksasin dengan diameter zona radikal sebesar 35,75 $\mathrm{mm}$ (Tabel 4).

Berdasarkan hasil di atas (Tabel 5) p value $<0.005$ sehingga terdapat perbedaan daya hambat variasi konsentrasi ekstrak etanol daun ketepeng china terhdap S. dysentriae.

Hasil identifikasi ulang dari kultur murni bakteri Shigella dysentriae yang dilakukan pada pengecatan gram diperoleh bakteri gram (-) batang berwarna merah. Pada media Mac Conkey terbentuk koloni irreguler dengan warna koloni tidak berwarna, membentuk elevasi datar dan tepian utuh, Shigella $d y$ sentriae tidak mampu memfermentasi laktosa.

Bakteri Shigella dysentriae merupakan bakteri gram negatif berukuran 0,5-0,7 $\mu \mathrm{g}$ x 2-3 $\mu \mathrm{g}$. Bentuk- 
nya batang pendek atau basil tunggal, tidak berspora, tidak berflagel sehingga tidak bergerak, dan memiliki kapsul. Dinding sel bakteri Gram negatif lebih banyak mengandung lemak dibandingkan Gram positif, yaitu $11-12 \%$ dan sedikit lapisan peptidoglikan. Sehingga struktur dinding sel bakteri merupakan penyebab terjadinya reaksi pewarnaan (Rahman, 2010). Teori Salton menjelaskan dinding sel bakteri Gram negatif mengandung kadar lipid tinggi, sekitar 20\%. Saat pewarnaan Gram, pencucian dengan sediaan alkohol 96\% untuk melarutkan lipid (Gram C) sehingga poripori dinding sel membesar dan zat warna (Gram A) yang sudah diiserap sel akan dilepaskan kembali, akibatnya bakteri tersebut tidak terwarnai kemudian ketika digenangi safranin (Gram D), bakteri akan menyerap cat warna tersebut sehingga bakteri berwarna merah (Radji, 2011).

Bakteri Shigella dysentriae bersifat fakultatif anaerob, tetapi tumbuh paling baik secara aerob. Koloni berbentuk konveks, bulat, transparan dengan tepi yang utuh dan mencapai diameter sekitar $2 \mathrm{~mm}$ dalam 24 jam. Shigella dysentriae memfermentasi glukosa, membentuk asam dari karbohidrat tetapi jarang menghasilkan gas, dan tidak memfermentasi manitol (Brooks et al., 2008).

Hasil Kruskal - Wallis didapatkan nilai signifikansi $(p)=0.000(\leq 0.05)$, disimpulkan ada pengaruh variasi konsentrasi ekstrak etanol daun ketepeng cina terhadap pertumbuhan Shigella dysentriae. Hal ini ditunjukkan dengan semakin meningkatnya konsentrasi ekstrak etanol daun ketepeng cina maka semakin besar pula diameter zona radikal. Pada konsentrasi $100 \%$ diperoleh rata-rata diameter zona radikal yaitu sebesar 8,5 mm, sedangkan konsentrasi 12,5\% sebesar 1,75 mm. Hasil penelitian ini kurang baik bila dibandingkan dengan penelitian sebelumnya Yacob dan Endriani (2010), dimana pada konsentrasi $100 \%$ rata-rata diameter zona hambat ekstrak etanol daun ketepeng cina terhadap Escherichia coli sebesar $10 \mathrm{~mm}$.

Beberapa faktor yang menyebabkan ekstrak etanol daun ketepeng cina memiliki aktivitas antibakteri untuk menghambat pertumbuhan Shigella dysentriae:

a. Tanin
Tanin merupakan golongan fenol yang memiliki efek astrigen, antibakteri, dan antioksidan. Secara kimia tanin dibagi menjadi dua golongan, yaitu tanin terkondensasi atau tanin katekin dan tanin terhidrolisis (Malangi, et al., 2012).

Senyawa tanin ini mampu menghambat enzim DNA-topoisomerase dan merusak membran sel sehingga sel bakteri tidak dapat terbentuk (Ngajow, et al., 2013).

\section{b. Saponin}

Saponin merupakan senyawa yang memiliki sifat antibakteri dan dapat menimbulkan busa dalam air jika dikocok dengan kuat. Saponin bekerja dengan mengganggu stabilitas membrane sel bakteri sehingga menyebabkan kematian sel (Zahro dan Agustini, 2013).

Hasil uji Post Hoc Mann - Whitney (Tabel 6) menunjukkan berbeda dengan konsentrasi 50\% menuju konsentrasi $100 \%$ memberikan nilai signifikan $(p)=0.001(\leq 0.05)$ berarti ada perbedaan signifikan variasi konsentrasi ekstrak etanol daun ketepeng cina.

Aktivitas konsentrasi $100 \%$ pada metode difusi cara cakram didapatkan hasil rata - rata diameter sebesar 8,5 mm tidak sebanding pada aktivitas yang ditunjukkan oleh kontrol positif ciprofloksasin $5 \mu \mathrm{g}$ dengan besar rata - rata diameter $35,75 \mathrm{~mm}$. Karena zat aktif seperti flavonoid yang terkandung dalam ekstrak etanol daun ketepeng cina akan rusak jika pada awal melakukan perlakuan ekstraksi tersebut melewati suhu tinggi (Rahayoe et al., 2008).

Pada pengenceran ekstrak etanol daun ketepeng cina dari konsentrasi $100 \%, 50 \%, 25 \%, 12,5 \%$ terjadi pengurangan zat aktif dari ekstrak etanol daun ketepeng cina sehingga aktivitas antibakterinya berkurang membuktikan bahwa pengenceran berefek terhadap kandungan senyawa aktif ekstrak etanol daun ketepeng cina. Semakin tinggi pengenceran, maka semakin berkurang senyawa aktif dalam ekstrak etanol daun ketepeng cina (Gambar 4).

Konsentrasi optimum adalah konsentrasi terendah dari variasi konsentrasi ekstrak etanol daun ketepeng cina yang menunjukkan beda siqnifikan dengan control (-), hal ini ditunjukkan pada Tabel 6. Zat antimikroba yang menghasilkan aktivitas penghambatan bakteri uji yang paling 


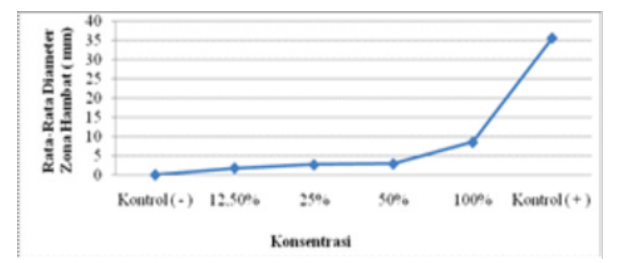

Gambar 4.Hasil Uji Aktivitas Antibakteri Metode Difusi Cakram

baik yaitu konsentrasi ekstrak etanol daun ketepeng cina $100 \%$ adalah konsentrasi optimum dalam penelitian ini yang sesuai dengan uji Post Hoc (Mann-Whitney).

Hasil penelitian ini zona hambat yang terbentuk lebih kecil dibandingkan dengan hasil Yacob \& Endriani (2010), yaitu untuk Escherichia coli sebesar $10 \mathrm{~mm}$ untuk konsentrasi 12,5\%. Sedangkan hasil penelitian ini juga lebih kecil dibandingkan yang dilakukan Ogunjobi dan Abiala (2013), mampu menghambat Escherichia coli sebesar 17,2 mm. Hal ini dapat disebabkan oleh faktor biologi dan faktor kimia dari tanaman Cassia alata Linn tersebut.

Bakteri Shigella dysentriae menggunakan perbandingan dengan Standar Mc Farland yang digunakan adalah nomor 0,5. Menurut Mukhitasari (2012) kepadatan bakteri yang terkandung adalah 1 x $10^{8} \mathrm{CFU} / \mathrm{ml}$, sesuai dengan perkiraan jumlah bakteri yang dapat menimbulkan efek patogen bila masuk ke dalam tubuh manusia, sedangkan jumlah organisme yang infektif pada manusia ialah $10^{3}$ dimungkinkan dari itulah yang menyebabkan zona hambat yang terbentuk kurang maksimal karena bakteri yang digunakan lebih banyak dari organisme infektifnya.

Penelitian ini menggunakan bakteri Shigella dysentriae yang berbeda dengan penelitian sebelumnya menggunakan bakteri Escherichia coli dengan zona hambat lebih besar dari pada penelitian ini. Bakteri Escherichia coli lebih sensitif terhadap aktivitas antibakteri dari ekstrak ketepeng cina. Sedangkan bakteri Shigella dysentriae mempunyai sensitifitas yang kurang terhadap aktivitas antibakteri dari ekstrak ketepeng cina hal ini mungkin disebab bahwa bakteri Shigella $d y$ sentriae mempunyai kemampuan membentuk proteksi terhadap aktivitas antibakteri ekstrak ketepeng cina. Adapun perbedaan kedua bakteri tersebut dalam jumlah organisme yang dapat menginfeksi manusia, Shigella dysentriae dapat menimbulkan infeksi dengan dosis $10^{3}$ sedangkan bakteri Escherichia coli dengan dosis sebesar $10^{6}$ - 10. Penelitian ini menggunakan Shigella $d y$ sentriae yang memiliki dosis infektif pada manusia sangat menular yaitu $10^{3}$ dan bakteri ini merupakan golongan Shigella spesies yang cenderung resisten terhadap antibiotik (Brooks et al., 2008).

\section{KESIMPULAN}

Variasi konsentrasi ekstrak etanol daun ketepeng cina (Cassia alata Linn) efektif menghambat pertumbuhan Shigella dysentriae dengan metode difusi cara cakram dan konsentrasi optimum adalah $100 \%$.

\section{DAFTAR PUSTAKA}

Abdullah, A.Z.,A.A.Arsin dan L.Dahlan.2012.Faktor Resiko Diare Shigellosis pada Anak Balita. Jurnal Kesehatan Masyarakat Nasional Vol 7(1) ISSN 1907-7505

Adila, R., Nurmiati, dan Anthoni A.2013. Uji Antimikroba Curcuma spp. Terhadap Pertumbuhan Candida albicans, Staphylococcus aureus, dan Escherichia coli. Jurnal Bioogi Universitas Andalas vol 2(1) ISSN 2303-2162

Brooks, G. F., Butel dan Morse. 2008. Mikrobiologi Kedokteran Edisi 23. Jakarta: Penerbit Buku Kedokteran EGC.

Chunaifi, M; Tukiran. 2014. Skrining Fitokimia dari Ekstrak Etil Asetat Kulit Batang Tumbuhan Nyiri Batu (Xylocarpus moluccencis). UNESA Journal of Chemistry 3 (3) pp 87 - 92.

Kurniawan, D., Wahyuningrum,R., Dhiani,B., 2012. Pengawet Alami Ekstrak Etanol Daun Ketepeng Cina pada Sediaan Sirup Herbal Tomat. Jurnal Vol 1.nomor 1:16-21

Malangngi, L. P; Sangi, M.S; Paedong, J.J.E. 2012. Penentuan Kandungan Tanin dan Uji Aktivitas Antioksidan Ekstrak Biji Buah Alpukat (Persea americana Mill.) Jurnal MIPA UNSRAT 1(1). PP 5-10.

Mukhitasari, D. A., 2012. Uji Aktivitas Antibakteri Perasan Jeruk Nipis (Citrus aurantifolia, Swingle) Terhadap Pertumbuhan Shigella dysentriae Secara In Vitro. Skripsi. FK Universitas Jember.

Ngajow, M; Abidjulu, J; Kamu, V.S. 2013. Pengaruh Antibakteri 
Ekstrak Kulit Batang Matoa (Pometia pinnata) terhadap Bakteri Staphylococcus aureus secara In vitro. Jurnal MIPA UNSRAT Online 2 (2) 128-132

Ogunjobi,A.A., Abiala,M.A., 2013. Antimicrobial Activity of Senna alata and Phyllanthus amarus, Global Jurnal of Pharmacology. Vol.7, No 2:198-202

Permatasari, G. A. A., I. N. K. Besung, dan H. Mahatmi. 2013. Daya Hambat Perasan Daun Sirsak Terhadap Pertumbuhan Bakteri Escherichia coli. Jurnal Indonesia Medicus Veterinus Vol 2(2): 162-169.

Radji, Maksum. 2011. Buku Ajar Mikrobiologi : Panduan Mahasiswa Farmasi \& kedokteran. Jakarta: EGC.

Rahayoe, R., Rahardjo, B., Kusumandari, Rr.S., 2008, Konstanta Laju Pengeringan Daun Sambiloto Menggunakan Pengering Tekanan Rendah, Yogyakarta. Skripsi. Fakultas Pertanian Universitas Gajah Mada Yogyakarta.

Rahman, F. A. 2010. Pewarnaan Gram. Malang: Universitas Muhammadiyah Malang.

Rahmithasuci, I. 2013. Keragaman Bakteri Endofit Pada Kultivar Nanas (Annas comosus (L) Merr) Simadu Dan Biasa Di Kabupaten Subang. Skripsi. Universitas Pendidikan Indonesia.
Sari, P P; Rita, W.S; Puspawati, N M. Identifikasi dan UjiAktivitas Senyawa Tanin dari Ekstrak Daun Trambesi (Samanea saman (Jacq.) Merr) sebagai Antibakteri Escherichia coli. Jurnal Kimia 9 (1) pp 27 - 34.

Sule, W.F., Okonko, I.O., Joseph, T.A., Ojezele, M.O., Nwanze, J.C., Alli, J.A., et al., 2010, In-vitro antifungal activity of Senna alata Linn. Crude leaf extract, Pelagia Research Library, 1(2): 14-26.

Timothy,S.Y., Lamu,F.W., Rhoda,A.S., Adiati,R.G., Maspalma, I.D., Askira,M., 2012. Antimicrobial Activity of Senna alata and Phyllanthus amarus. International Research Journal of Pharmacy. ISSN:2252-7168

World Health Organization. 2009. Who fact sheet of diarrheal disease. www.who.int diakses pada 1 September 2016

Yacob, T., Endriani, R., 2010. Daya Antibakteri Ekstrak Etanol Ketepeng Cina (Senna alata) terhadap Staphylococcus aureus dan Escherichia coli secara In Vitro. Jurnal Natur Indonesia 13(1):63-66.

Zahro, L; Agustini, R. 2013. Uji Efektivitas Antibakteri Ekstrak Kasar Saponin Jamur Tiram Putih (Pleurotus ostreatus) terhadap Staphylococcus aureus dan Escherichia coli. UNESA Journal of Chemistry2 (3) pp 120-129. 